\title{
MINERALOGICAL ABSTRACTS FROM SCIENTIFIC PAPERS PUBLISHED IN JAPAN,
}

\section{Edited by the Abstracting Committee, Japan Association of Mineralogical Sciences*}

\author{
Ore Minerals and Economic Geology \\ Porphyry Copper Deposits 105012-105017; \\ Massive Sulfide Deposits 105018-105025
}

\section{Ore Minerals and Economic Geology \\ Porphyry Copper Deposits}

105012 Ramírez, L. E., Parada, M. A., Palacios, C. \& Witten-

brink, J. Magmatic evolution of the Mantos Blancos copper deposit, Coastal Range of northern Chile: insight from $\mathrm{Sr}-\mathrm{Nd}$ isotope, geochemical data and silicate melt inclusions. Resource Geol., 58, 124-142, 10 figs, 3 tables, 1 appendix, 2008.

The Mantos Blancos copper deposit $(500 \mathrm{Mt}$ at $1.0 \% \mathrm{Cu})$ was affected by two superimposed hydrothermal events: (i) phyllic alteration related to a rhyolitic dome emplacement and brecciation at ca $155 \mathrm{Ma}$; and (ii) potassic, sodic and propylitic alteration at ca $142 \mathrm{Ma}$, coeval with stocks and sills emplacement of dioritic and granodioritic porphyries, that locally grade upwards into polymictic magmatic hydrothermal breccias. Major hypogene copper sulfide mineralization is related to the second event. A late-ore mafic dike swarm cross-cuts all rocks in the deposit. Two types of granodioritic porphyries can be distinguished from petrographic observations and geochemical data: granodiorite porphyry I (GP I) and granodiorite porphyry II (GP II), which resulted from two different trends of magmatic evolution. The concave shape of the rare earth element (REE) distribution pattern together with the weak or absence of negative Eu anomalies in mafic dikes, dioritic and GP I porphyries, suggest hornblende-dominated fractionation for this magmatic suite. In contrast, distinct negative Eu anomalies and the flat REE patterns suggest plagioclase-dominated fractionation, at low oxygen fugacity, for the GP II porphyry suite. But shallow mixing and mingling between silicic and dioritic melts are also likely for the formation of the GP II and polymictic breccias, respectively. $\mathrm{Sr}-\mathrm{Nd}$ isotopic compositions suggest that the rhyolitic dome rocks were generated from a dominantly crustal source, while the GP I has mantle affinity. The composition of melt inclusions (MI) in quartz crystals from the rhyolitic dome is similar to the bulk composition of their host rock. The MI analyzed in quartz from GP II and in the polymictic magmatic hydrothermal breccia of the deposit are compositionally more evolved than their host rocks. Field, geochemical and petrographic data provided here point to dioritic and siliceous melt interaction as an inducing mechanism for the release of hydrothermal fluids to form the $\mathrm{Cu}$ mineralization.

(Authors' abstract)

105013 Li, X. \& Sasaki, M. Hydrothermal alteration and mineralization of middle Jurassic Dexing porphyry $\mathrm{Cu}-\mathrm{Mo}$ deposit, Southeast China. Resource Geol., 57, 409-426, 11 figs, 5 tables, 2007.

The Dexing deposit in the southeastern margin of the Yangtze Craton is the largest porphyry copper deposit in China, consisting of three porphyry copper orebodies of Zhushahong, Tongchang and Fujiawu from northwest to southeast. It contains $1168 \mathrm{Mt}$ of ores with $0.5 \% \mathrm{Cu}$ and $0.01 \%$ Mo. The Dexing deposit is hosted by

\footnotetext{
*Abstracting Committee

I. Sunagawa (Chairman and Editor)

R. Miyawaki (Technical Editor)

Y. Banno, T. Hokada, K. Kihara, T. Minakawa, H. Miura,

T. Mizuta, T. Nagase, T. Noguchi, F. Ohashi, M. Ohkawa,

E. Ohtani, K. Onuma, T. Sano, N. Sasaki, T. Takagi, K. Tomita,

K. Tsukamoto, S. Uehara, J. Yamakawa
}

Middle Jurassic granodiorite porphyries and pelitic schist of Proterozoic age. The Tongchang granodiorite porphyry has a medium $\mathrm{K}$ cal-alkaline series, with medium $\mathrm{K}_{2} \mathrm{O}$ content (1.94-2.07 wt $\%)$, and low $\mathrm{K}_{2} \mathrm{O} /\left(\mathrm{Na}_{2} \mathrm{O}+\mathrm{K}_{2} \mathrm{O}\right)(0.33-0.84)$ ratios. They have high large-ion lithophile elements, high light rare-earth elements, and low high-field-strength elements. The hydrothermal alteration at Tongchang is divided into four alteration mineral assemblages and related vein systems. They are early $\mathrm{K}$-feldspar alteration and A vein; transitional (chlorite + illite) alteration and $\mathrm{B}$ vein; late phyllic (quartz + muscovite) alteration and $D$ vein; and latest carbonate, sulfate and oxide alteration and hematite veins. Primary fluid inclusions in quartz from phyllic alteration assemblage include liquid-rich (type 1), vapor-rich (type 2) and halitebearing ones (type 3 ). These provide trapping pressures of 20-400 $\times 10^{5} \mathrm{~Pa}$ of fluids responsible for the formation of $\mathrm{D}$ veins. Igneous biotite from least altered granochiorite porphyry and hydrothermal muscovite in mineralized granodiorite porphyry possess $\delta^{18} \mathrm{O}$ and $\delta \mathrm{D}$ values of $4.6 \%$ and $-87 \%$ for biotite and $7.1-8.9 \%,-71$ to $-73 \%$ for muscovite. Stable isotopic composition of the hydrothermal water suggests a magmatic origin. The carbon and oxygen isotope for hydrothermal calcite are -4.8 to $-6.2 \%$ and $6.8-18.8 \%$, respectively. The $\delta^{34} \mathrm{~S}$ of pyrite in quartz vein ranges from -0.1 to $3 \%$, whereas $\delta^{34} \mathrm{~S}$ for chalcopyrite in calcite veins ranges from 4 to $5 \%$. These are similar to the results of previous studies, and suggest a magmatic origin for sulfur. The involvement of hydrothermal fluids exsolved from a crystallizing melt are responsible for the formation of Tongchang porphyry $\mathrm{Cu}-\mathrm{Mo}$ orebodies.

(T. Takagi)

105014 Imai, A., Shinomiya, J., Maung, T. S., Setijadji, L. D., Watanabe, K. \& Warmada, I. W. Porphyry-type mineralization at Selogiri area, Wonogiri regency, central Java, Indonesia. Resource Geol., 57, 230-240, 10 figs, 1 table, 2007.

The Selogiri area, situated in Wonogiri regency, Central Java, is one of several gold prospecting areas in the Southern areas Mountain Range in Java, Indonesia. Three types of dioritic-andesitic intrusive rocks occur in the Selogiri area, namely, hornblende andesite porphyry, hornblende diorite porphyry and hornblende diorite, exposed in a half-circular depression where volcanic breccia and tuff are widely distributed. The occurrence of stockwork quartz veinlets and associated with magnetite and malachite coating along the cracks in the diorite porphyry suggests porphyry type mineralization. This is also supported by the occurrence of polyphase hypersaline fluid inclusions in the stockwork veinlet quartz. Small-scale miners are mining NS-trending quartz veins for gold associated with base metal sulfides. These veins are probably epithermal-type mineralization that overprinted porphyry-type mineralization. The Neogene intermediate to silicic hydrous magmatism in Java could have formed the porphyry-type mineralization in Selogiri, as in the rest of the SundaBanda arc.

(Authors' abstract)

105015 Suerte, L. O., Nishihara, S., Imai, A., Watanabe, K., Yumul Jr, G. P. \& Maglambayan, V. B. Occurrences of ore minerals and fluid inclusion study on the Kingking porphyry copper-gold deposit, eastern Mindanao, Philippines. Resource Geol., 57, 219-229, 13 figs, 2007.

The Kingking deposit is a gold-rich porphyry copper deposit in the eastern Mindanao mineralized belt, Philippines. The main alteration zones in the deposit are the inner potassic zone and the outer propylitic zone. The biotite-bearing diorite and hornblende diorite porphyries are the primary host rocks of mineralization. 
Two dominant copper minerals, bornite and chalcopyrite, which usually occur as fracture fillings, are associated with fine crystalline quartz veinlet stockworks in the mineralized diorites. Minor secondary covellite, chalcocite and digenite are also observed. The primary $\mathrm{Cu}-\mathrm{Fe}$ sulfide phases initially deposited from ore fluids consisted of bornite solid solution (bnss) and intermediate solid solution (iss), which decomposed to form the bornite and chalcopyrite. Peculiar bornite pods that are different from dissemination and are associated with volcanic rock xenoliths in biotitebearing diorite porphyry are noted in a drill hole. These pods of bornite are not associated with quartz veinlet stockworks. Fluid inclusion analyses show three types of inclusions contained in Kingking samples: two-phase fluid-rich and vapor-rich inclusions and polyphase hypersaline inclusions from porphyry-type quartz veinlet stockworks. The liquid-vapor homogenization temperatures $(\mathrm{TH})$ and the dissolution temperature of halite daughter crystals (TM) from the polyphase hypersaline inclusions predominantly range from $400^{\circ} \mathrm{C}$ up to $>500^{\circ} \mathrm{C}$. The wide range of $\mathrm{TH}$ and TM may be due to heterogeneous trapping of variable ratios of vapor and brine. For some inclusions, TH $>$ TM and in some cases, $\mathrm{TH}<\mathrm{TM}$, indicating that some of the brine was supersaturated or saturated with $\mathrm{NaCl}$ at the time of entrapment. Calculated salinity of the polyphase hypersaline inclusions ranges from 40 to $60 \%$ $\mathrm{NaCl}$ equivalent. Temperature and vapor pressure of mineralized fluid were estimated to be $400^{\circ} \mathrm{C}$ and $16 \mathrm{MPa}$.

(T. Takagi)

105016 Imai, A., Ohbuchi, Y., Tanaka, T., Morita, S. \& Yasunaga, K. Characteristics of porphyry Cu mineralization at Waisoi (Namosi District), Viti Levu, Fiji. Resource Geol., 57, 374-385, 10 figs, 2 tables, 2007.

The porphyry $\mathrm{Cu}$ deposits at Waisoi in Namosi district, Viti Levu are separated into two deposits: the Waisoi East deposit and the Waisoi West deposit. In the Waisoi East deposit, quartz porphyry is exposed and in the Waisoi West deposit, diorite porphyry is sporadically exposed in addition to a small body of quartz porphyry. The mineralization in the Waisoi East deposit is characterized by the bornite-chalcopyrite-pyrite assemblage associated with traces of molybdenite and native gold. Polyphase fluid inclusions in stockwork quartz veinlets show homogenization temperatures ranging from 210 to $>500^{\circ} \mathrm{C}$. The high-grade $\mathrm{Cu}$ mineralization in the Waisoi West deposit is characterized by the bornitechalcopyrite-pyrite assemblage accompanied with sheeted and stockwork quartz veinlets. Polyphase fluid inclusions occasionally containing hematite flakes in quartz veinlets in the center of the Waisoi West deposit homogenize at temperatures ranging from $450^{\circ} \mathrm{C}$ to $>500^{\circ} \mathrm{C}$. However, fluid inclusions in stockwork quartz veinlets in the periphery, homogenize at lower temperatures around $210^{\circ} \mathrm{C}$. Both in the Waisoi East and Waisoi West deposits, primary bornite-chalcopyrite-pyrite assemblage in the high $\mathrm{Cu}^{-}$ grade zone was deposited at the upper stability limit of chalcopyrite with respect to sulfur fugacity. Thus, the principal $\mathrm{Cu}$ mineralization at the Waisoi deposits occurred at a relatively high sulfur fugacity, that is, in a high-sulfidation environment.

(Authors' abstract)

105017 Taghipour, N., Aftabi, A. \& Mathur, R. Geology and ReOs geochronology of mineralization of the Miduk porphyry copper deposit, Iran. Resource Geol., 58, 143-160, 8 figs, 6 tables, 2008.

The Miduk porphyry copper deposit is located in Kerman province, $85 \mathrm{~km}$ northwest of the Sar Cheshmeh porphyry copper deposit, Iran. The deposit is hosted by Eocene volcanic rocks of andesitic-basaltic composition. The porphyry-type mineralization is associated with two Miocene calc-alkaline intrusive phases (P1 and P2, respectively). Five hypogene alteration zones are distinguished at the Miduk deposit, including magnetite-rich potassic, potassic, potassic-phyllic, phyllic and propylitic. Mineralization occurs as stockwork, dissemination and nine generations (magnetite, quartz-magnetite, barren quartz, quartz-magnetite-chalcopyrite-anhydrite, chalcopyrite-anhydrite, quartz-chalcopyriteanhydrite-pyrite, quartz-molybdenite- anhydrite \pm chalcopyrite \pm magnetite, pyrite, and quartz-pyrite-anhydrite \pm sericite) of veinlets and veins. Early stages of mineralization consist of magnetite rich veins in the deepest part of the deposit and the main stage of mineralization contains chalcopyrite, magnetite and anhydrite in the potassic zone. The high intensity of mineralization is associated with P2 porphyry (Miduk porphyry). Based on petrography, mineralogy, alteration halos and geochemistry, the Miduk porphyry copper deposit is similar to those of continental arc setting porphyry copper deposits. The Re-Os molybdenite dates provide the timing of sulfide mineralization at $12.23 \pm 0.07 \mathrm{Ma}$, coincident with $\mathrm{U} / \mathrm{Pb}$ zircon ages of the $\mathrm{P} 2$ porphyry. This evidence indicates a direct genetic relationship between the Miduk porphyry stock and molybdenite mineralization. The Re-Os age of the Miduk deposit marks the main stage of magmatism and porphyry copper formation in the Central Iranian volcano-plutonic belt.

(Authors' abstract)

\section{Massive Sulfide Deposits}

105018 Liu, L.-M. \& Zhang, Y. Numerical modeling of the coupled mechanical and hydrological processes during deformation and mineralization in the Mount Isa Block, Australia. Resource Geol., 57, 283-300, 10 figs, 3 tables, 2007.

The wide varieties of $\mathrm{Pb}-\mathrm{Zn}-\mathrm{Ag}$ mineralization in the Mount Isa province are believed to be closely related to the geodynamic processes of Isan Orogeny, which occurred between ca 1500 and $1620 \mathrm{Ma}$. In order to understand the geodynamic processes associated with the Isan Orogeny and the giant mineralization systems in the Mount Isa district, a series of numerical models has been constructed to simulate coupled mechanical-hydrological processes, using Fast Lagrangian Analysis of Continua (FLAC), a finite difference computer code. The numerical modeling results have demonstrated that the most probable far-field stress orientation during the Isan Orogeny is the asymmetrical E-W shortening, which led to greater easternward tectonic movement at the west boundary of the district in comparison with westward movement at the east boundary. During the initial and early stage of the Isan Orogeny, the mechanical and hydrological conditions in the Leichardt Fault Trough of the West Fold Belt are much more favorable for fluid accumulation and mineralization than in the East Fold Belt. The Mount Isan fault zone developed as a high dilation shear zone where the fluids were focused. As the asymmetrical shortening progressed, shortening deformation and shear strain localization became intensified in the eastern part of the orogenic district. The eastern region therefore became a more favorable locality for hydrothermal mineralization. This structural development feature seems to explain why mineralization in the East Fold Belt is generally later than in the West Fold Belt. Fluid production from the Williams-Naraku granites could result in fluid overpressuring, and this probably contributed to the extensive brecciation and related mineralization in the East Fold Belt. (T. Takagi)

105019 Glasby, G. P., Maslennikov, V. V., Prozherova, I. A. \& Petukhov, S. I. Jusa and Barsuchi Log volcanogenic massive sulfide deposits from the southern Urals of Russia: Devonian analogs of the Kuroko deposits of NE Honshu, Japan. Resource Geol., 58, 313-324, 1 fig, 2008.

Chemical analysis of 60 samples from the Jusa and Barsuchi Log volcanogenic massive sulfide (VMS) deposits by ICP-MS shows that, on average, the Jusa deposit is more enriched in the chalcophilic elements than the Barsuchi Log deposit, whereas the Barsuchi Log deposit is more enriched in the lithogenous elements and Te. In addition, the yellow ores in these deposits are more en- 
riched on average in $\mathrm{Cu}$, As and Mo and the black ores more enriched in $\mathrm{Zn}, \mathrm{Ga}, \mathrm{Cd}, \mathrm{Sb}, \mathrm{Ba}, \mathrm{Hg}$ and $\mathrm{Pb}$ relative to each other. Both these deposits are similar in composition to the Kuroko deposits of NE Honshu and may be considered to be analogs of these deposits. The Kuroko deposits, however, contain much higher concentrations of As, $\mathrm{Ag}, \mathrm{Sb}, \mathrm{Ba}, \mathrm{Hg}$ and lower contents of Te on average than the Jusa and Barsuchi Log deposits. Based on the higher contents of Te in the Barsuchi Log deposit compared to the Jusa deposit, as well as on textural considerations, it is concluded that the Barsuchi Log deposit is intermediate between the Uralsand Kuroko-type deposits, whereas the Jusa deposit is more analogous to the Kuroko-type deposits. Based on the compositional data presented here, the Jusa and Barsuchi Log deposits may be described as $\mathrm{Zn}-\mathrm{Pb}-\mathrm{Cu}-\mathrm{Ba}$ deposits rather than as $\mathrm{Zn}-\mathrm{Cu}-\mathrm{Ba}$ deposits, as the Baimak-type deposits of the west Magnitogrosk zone have previously been described.

(Authors' abstract)

105020 Tanahashi, M., Fujioka, K. \& Machida, S. Myojin Rift, Izu-Bonin Arc as the modern analog of Hokuroku Basin, Northeast Japan: Geotectonic significance of the new hydrothermal deposit in the back-arc rift. Resource Geol., 58, 301-312, 8 figs, 1 table, 2008.

A huge hydrothermal field, named the "Hakurei Sulfide Deposit" (HSD) was discovered in the North Myojin Rift (NMR), Izu-Bonin Back-Arc Rift (BAR). The topographic features of the NMR and the Hokuroku Basin have a clear ring structure surrounded by faults showing almost the same E-W width. Many kuroko deposits were formed on the extrusion centers of the five premineral acidic volcanic complexes, located in a loop inside the Hokuroku Basin. In NMR, seven submarine volcanoes are also located in a loop, and the HSD formed inside the summit caldera of Bayonnaise Knoll, which is one of the seven volcanoes. These topographic similarities highlight that the NMR is a modern analog of the Hokuroku Basin. Identifying such similarities is extremely useful when prospecting kuroko deposits on land equivalents as well as on the other segments of the Izu-Bonin BAR. The probability of finding kuroko deposits on land is expected to increase when the following are identified: (i) location of back-arc rift and the volcanic front; (ii) direction of the arc-trench system and intra-rift faults (and/or fracture zone); (iii) position of submarine volcanoes surrounding a back-arc rift; and (iv) intersections of a caldera fault and intra-rift fault (and/or fracture zone) inside the summit caldera of submarine volcanoes.

(T. Takagi)

105021 Nakaseama, M., Ishibashi, J., Ogawa, K., Hamasaki, H., Fujino, K. \& Yamanaka, T. Fluid-sediment interaction in a Marine shallow-water hydrothermal system in the Wakamiko submarine crater, South Kyushu, Japan. Resource Geol., 58, 289-300, 8 figs, 3 tables, 2008.

Marine shallow-water hydrothermal activity associated with fumarolic gas emissions at the Wakamiko submarine crater sea floor (water depth $200 \mathrm{~m}$ ) is considered to be related with magmatic activity of the Aira Caldera. An active shimmering site was discovered (tentatively named the North site) at approximately 1 $\mathrm{km}$ from the previously known site (tentatively named the South site) by remotely operated vehicle Hyper-Dolphine. Surface sediment $(\leq 30 \mathrm{~cm})$ was cored from six localities including these active sites. The pore fluids of these sites showed a drastic change in chemical profile from that of seawater, even at $30 \mathrm{~cm}$ below the surface, which is attributed to mixing of the ascending hydrothermal component and seawater. The hydrothermal component of the North site is estimated to be derived from a hydrothermal aquifer at $230^{\circ} \mathrm{C}$ based on the hydrothermal end-member composition. Occurrence of illite/smectite interstratified minerals in the North site sediment is attributed to in situ fluid-sediment interaction at a temperature around $150^{\circ} \mathrm{C}$, which is in accordance with the pore fluid chemistry. In contrast, montmorillonite was identified as the dominant alteration mineral in the South site sediment. Together with the significant low $\mathrm{K}$ concentration of the hydrothermal endmember, the abundant occurrence of low-temperature alteration mineral suggests that the hydrothermal aquifer in the South site is not as high as $200^{\circ} \mathrm{C}$. Moreover, the montmorillonite is likely to be unstable with the present pore fluid chemistry at the measured temperature $\left(117^{\circ} \mathrm{C}\right)$. This disagreement implies unstable hydrothermal activity at the South site, in contrast to the equilibrium between the pore fluid and alteration minerals in the North site sediment. This difference may reflect the thermal and/or hydrological structure of the Wakamiko Crater hydrothermal system.

(T. Takagi)

105022 Suzuki, R., Ishibashi, J., Nakaseama, M., Konno, U., Tsunogai, U., Gena, K. \& Chiba, H. Diverse range of mineralization induced by phase separation of hydrothermal fluid: Case study of the Yonaguni Knoll IV hydrothermal field in the Okinawa Trough back-arc basin. Resource Geol., 58, 267-288, 15 figs, 5 tables, 2008.

The collected venting fluids from the Yonaguni Knoll IV field using the submersible Shinkai 6500 had a wide range of chemistry ( $\mathrm{Cl}$ concentration $376-635 \mathrm{mmol} \mathrm{kg}^{-1}$ ), which is considered as evidence for sub-seafloor phase separation. While the $\mathrm{Cl}$-enriched smoky black fluids were venting from two adjacent chimneymound structures in the hydrothermal center, the clear transparent fluids sometimes containing $\mathrm{CO}_{2}$ droplet were found in the peripheral area of the field. The collected hydrothermal precipitates demonstrated a diverse range of mineralization, which can be classified into five groups: (i) anhydrite-rich chimneys, immature precipitates including sulfide disseminations in anhydrite; (ii) massive $\mathrm{Zn}-\mathrm{Pb}-\mathrm{Cu}$ sulfides, consisting of sphalerite, wurtzite, galena, chalcopyrite, pyrite, and marcasite; (iii) $\mathrm{Ba}-\mathrm{As}$ chimneys, composed of barite with sulfide disseminations, sometimes associated with realgar and orpiment overgrowth; (iv) Mn-rich chimneys, consisting of carbonates (calcite and magnesite) and sulfides (sphalerite, galena, chalcopyrite, alabandite, and minor amount of tennantite and enargite); and (v) pavement, silicified sediment including abundant native sulfur or barite. Sulfide/sulfate mineralization (groups i-iii) was found in the chimney-mound structure associated with vapor-loss (Cl-enriched) fluid venting. In contrast, the sulfide/carbonate mineralization (group iv) was specifically found in the chimneys where vapor-rich (Cl-depleted) fluid venting is expected, and the pavement (group v) was associated with diffusive venting from the seafloor sediment. This correspondence strongly suggests that the subseafloor phase separation plays an important role in the diverse range of mineralization in the Yonaguni IV field. The observed sulfide mineral assemblage was consistent with the sulfur fugacity calculated from the FeS content in sphalerite/wurtzite and the fluid temperature for each site, which suggests that the shift of the sulfur fugacity due to participation of volatile species during phase separation is an important factor to induce diverse mineralization. In contrast, carbonate mineralization is attributed to the significant mixing of vapor-rich hydrothermal fluid and seawater.

(T. Takagi)

105023 Kakegawa, T., Utsumi, M. \& Marumo, K. Geochemistry of sulfide chimneys and basement pillow lavas at the Southern Mariana Trough $\left(12.55^{\circ} \mathrm{N}-12.58^{\circ} \mathrm{N}\right)$. Resource Geol., 58, 249-266, 10 figs, 4 tables, 2008.

Three submarine hydrothermal sites (Snail, Y and Pika sites) in the southern Mariana area were investigated to clarify the geochemical difference between off- axis and on-axis submarine hydrothermal activities and volcanic rocks. The Snail and Y sites are located on the axis of the spreading ridge, and the Pika site is located on the off-axis region. Low-temperature venting of submarine hydrothermal fluids was observed at the Snail and $\mathrm{Y}$ sites. High-temperature black smoker activities were found at the Pika 
site. Basement short drill cores of volcanic rocks and sulfides were also obtained from the Snail and Pika sites using a multi-coring system of manned submersible Shinkai 6500. All drilled pillow lavas were tholeiitic andesite with a narrow range of chemical variation. Significant enrichments of $\mathrm{Rb}, \mathrm{Ba}$ and $\mathrm{Th}$ were absent in both on-axis ( $Y$ and Snail sites) and off-axis (Pika site) samples, suggesting the least incorporation of subducting sediments to the magmatic system. Concentrations of $\mathrm{Au}$ and $\mathrm{Ag}$ in the sulfide chimney were within the range of massive sulfides at the midocean ridge rather than typical arc-type massive sulfides. It is found that sulfur isotope compositions of sulfides were different between the on-axis and off-axis samples: on-axis samples had heavy $\delta^{34} \mathrm{~S}(+2.9$ to $+8.7 \%$ ) and off- axis samples $(-0.3$ to $+3.8 \%$ ) were similar to the local magmatic value. Such a regional difference probably results from changes of deep hydrothermal processes during the water-rock interaction rather than differences in tectonic settings.

(T. Takagi)

105024 Saisuttichai, D. \& Manning, D. A. C. Geochemical characteristics and expansion properties of a highly potassic perlitic rhyolite from Lopburi, Thailand. Resource Geol., 57, 301-312, 8 figs, 5 tables, 2007.

Miocene volcanic rocks from northeast of Lopburi, Thailand, include a suite of highly potassic $\left(<6.3 \% \mathrm{~K}_{2} \mathrm{O}\right)$ perlitic rhyolites that are similar chemically to rhyolites from Sardinia (which are also perlitic) and Vulcano. Electron microprobe analysis using a defocused beam has shown that glass compositions contain up to $12.9 \% \mathrm{~K}_{2} \mathrm{O}\left(0.9 \% \mathrm{Na}_{2} \mathrm{O}\right)$, and within the same samples spherulites are enriched in $\mathrm{Na}_{2} \mathrm{O}(<6.2 \%)$ and depleted in $\mathrm{K}_{2} \mathrm{O}(2.1 \%)$. The perlitic rhyolites contain up to $4 \%$ water of meteoric origin; from Fourier transform infra-red spectroscopy data, expansion on heating involves a reduction in both hydroxyl and molecular water contents. When expanded using a laboratory test furnace, specific gravities as low as $26 \mathrm{~kg} / \mathrm{m}^{3}$ have been achieved for a $0.15-$ $0.3-\mathrm{mm}$ feed size fraction (reference perlite ores from Milos and Sardinia gave 47 and $33 \mathrm{~kg} / \mathrm{m}^{3}$, respectively), and $10 \mathrm{~kg} / \mathrm{m}^{3}$ for a 0.5-1-mm fraction separated after expansion. Expansion involves the loss of fluorine from the perlite, presumably as HF; unexpanded perlite contains $90-550 \mathrm{mg} / \mathrm{kg} \mathrm{F}$, which is reduced on expansion by $4-65 \%$. Water-soluble fluorine after expansion is increased by a factor of 10 up to $3.3 \mathrm{mg} / \mathrm{kg}$. Expansion also increases the availability of $\mathrm{K}$ to plants by a factor of up to 6 , with a maximum available $\mathrm{K}$ content of $1245 \mathrm{mg} \mathrm{K} / \mathrm{kg}$ perlite. This contrasts markedly with the chemically inert character of other, commercial, perlites, suggesting that the distinctive $\mathrm{K}$-enrichment of the perlitic rhyolite has given a raw material capable of generating products with nutritional functionality for plant growers.
(Authors' abstract)

105025 Marumo, K., Urabe, T., Goto, A., Takano, Y. \& Nakaseama, M. Mineralogy and isotope geochemistry of active submarine hydrothermal field at Suiyo Seamount, IzuBonin Arc, West Pacific Ocean. Resource Geol., 58, 220248, 15 figs, 5 tables, 2008.

The mineralization and hydrothermal alteration developed in a caldera on the summit of the Suiyo Seamount in the Izu-Bonin Island Arc below the $300 \times 150-\mathrm{m}$ area of active venting was investigated to depths of 2-9 m below the sea floor. No massive sulfide was found, however, and the subsea-floor mineralization to 10 $\mathrm{m}$ depth is dominated by anhydrite and clay minerals with some sulfides. Sulfide-bearing samples contained high $\mathrm{Au}(\leq 42 \mathrm{ppm})$, $\mathrm{Ag}(\leq 263 \mathrm{ppm}), \mathrm{As}(\leq 1550 \mathrm{ppm}), \mathrm{Hg}(\leq 55 \mathrm{ppm}), \mathrm{Sb}(\leq 772 \mathrm{ppm})$, and $\mathrm{Se}(\leq 24 \mathrm{ppm})$. The sulfides were also characterized by high $\mathrm{Zn}(>10 \%)$ compared to $\mathrm{Cu}(<6.3 \%)$ and $\mathrm{Pb}(<0.6 \%)$. The $\delta^{202} \mathrm{Hg} /$ ${ }^{198} \mathrm{Hg}, \delta^{202} \mathrm{Hg} /{ }^{199} \mathrm{Hg}$ and $\delta^{202} \mathrm{Hg} /{ }^{200} \mathrm{Hg}$ of the sulfide-bearing dacite samples and a sulfide chimney decreased with increasing $\mathrm{Hg} / \mathrm{Zn}$ concentration ratio. The large range of these $\delta^{202} \mathrm{Hg} /{ }^{198} \mathrm{Hg}(-2.8$ to $+0.5 \%$ to relative to $\mathrm{S}-\mathrm{HG} 02027$ ) was greater than might be expected for such a heavy element and may be due to a predominance of kinetic effects. The variation of $\delta^{202} \mathrm{Hg} /{ }^{198} \mathrm{Hg}$ of sulfidebearing dacite samples suggested that light $\mathrm{Hg}$ isotope in the vapor mixed with oxygenated seawater near sea floor during mineralization. $\mathrm{Pb}$ isotope ratios of the sulfide were very similar to those of the dacite lava, suggesting that $\mathrm{Pb}$ is of magmatic origin. The ${ }^{87} \mathrm{Sr} /{ }^{86} \mathrm{Sr}$ ratio $(0.70872)$ of anhydrite was different from that of the dacite lava, and suggests an $\mathrm{Sr}$ derivation predominantly from seawater. Hydrothermal clay minerals changed with depth from montmorillonite to chlorite/montmorillonite mixed-layer minerals to chlorite and mica. Hydrogen isotope ratios of chlorite/montmorillonite and mixed-layer, mica-chlorite composites obtained below the active venting sites ranged from -49 to $-24 \%$, suggesting seawater as the dominant fluid causing alteration. Oxygen isotope ratios of anhydrite ranged from 9.2 to $10.4 \%$ and anhydrite formation temperatures were calculated to be $188-207^{\circ} \mathrm{C}$. Oxygen isotope ratios ranged from +5.2 to $+9.2 \%$ for montmorillonite, +3.2 to $+4.5 \%$ for chlorite/montmorillonite mixed-layer minerals, and +2.8 to $+3.8 \%$ in mixtures of chlorite and mica. The formation temperatures of montmorillonite and of the chlorite-mica mixture were $160-250^{\circ} \mathrm{C}$ and $230-270^{\circ} \mathrm{C}$, respectively. The isotope temperatures for clay minerals $\left(220-270^{\circ} \mathrm{C}\right)$ and anhydrite $\left(188^{\circ} \mathrm{C}\right)$ were significantly lower than the borehole temperature $\left(308.3^{\circ} \mathrm{C}\right)$ measured just after the drilling, suggesting that temperature at this site is now higher than when clay minerals and anhydrite were formed.

(T. Takagi) 